Vol. 1, No. 2, Juni 2021

\title{
PENYULUHAN PEMANFAATAN MODAL BERBASIS SYARIAH BAGI PENGUSAHA PEMULA DI LINGKUNGAN GRISAK KELURAHAN KEKALIK JAYA
}

\author{
Muhammad Irwan \\ Fakultas Ekonomi dan Bisnis Universitas Mataram \\ dae.wan65@yahoo.com \\ Titiek Herwanti. \\ Fakultas Ekonomi dan Bisnis Universitas Mataram \\ titiekherwanti2@gmail.com \\ Siti Maryam \\ Fakultas Ekonomi dan Bisnis Universitas Mataram \\ maryamnanang@gmail.com \\ Eka Agustiani \\ Fakultas Ekonomi dan Bisnis Universitas Mataram \\ ekaagustiani27@gmail.com
}

Article History:
Received: 31 Maret 2021
Revised: -
Accepted: 6 Juni 2021
DOI:
10.29303/abdimassangkabi
ra.v1i2.31

Abstrak: Tujuan kegiatan Pengabdian Kepada Masyarakat adalah: (a) Memberikan Pengetahuan dan Pemahaman Kepada Pengusaha Pemula tentang hal-hal yang berkaitan dengan kewiraushaan syariah, (b) Memberikan pemahaman tentang sumber-sumber modal dari lembaga keuangan baik bank maupun non bank yang cara pengelolaannya dilakukan secara syariah, (c) Memberikan bantuan tambahan modal kepada Pengusaha Pemula baik yang baru atau sudah menjalankan usahanya dan cara memanfaatkan modal tersebut secara syariah. Solusi yang dilakukan untuk mencapai tujuan adalah: (a) Memberikan pemahaman dan pengetahuan yang berkenaan dengan sumber dan pengelolaan modal usaha melalui pertemuan terbatas dengan metode ceramah dan diskusi, (b) Mendampingi dan memantau perkembangan usaha melalui pemanfaatan modal baik modal sendiri maupun modal dari pihak luat (pinjaman), (c) Memberi bantuan modal usaha sebagai dasar untuk melakukan usaha sekaligus membentuk kelompok usaha.Kegiatan ini dikatakan berjalan baik dilihat dari beberapa indikator yaitu: (a) Kehadiran peserta yang melebihi syarat minimum, terdiri dari peserta laki - laki dan perempuan, (c) Diskusi dan tanya jawab yang memberikan gambaran tentang 
permasalahan yang dihadapi peserta terutama berkenaan dengan modal usaha yang berbasis syariah, (d) Peserta bersedia untuk mendukung serta menjadi anggota koperasi syariah yang akan dibentuk kelak setelah perjalan modal awal dari kegiatan ini terus mengalami perkembangan baik dari jumlah modal maupun jumlah peminjam.

Saran berkenaan dengan kegiatan ini adalah (a) Tim harus menindaklanjuti keinginan peserta untuk memberikatan pelatihan kewirausahaan sekaligus membentuk lembaga keuangan non bank sejenis koperasi berbasis syariah, (b) Diperlukan alokasi dana pengabdian yang proporsional dengan kegiatan yang akan dilaksanakan pada masa mendatang, (c) Penyajian tim masih dalam bentuk ceramah, dikembangkan dalam bentuk pendidikan seperti mempraktekkan langkah-langkah memulai usaha dan modal pendukungnya.

Kata Kunci: Pengusaha Pemula, Pengelolaan, Diversifikasi, Keuangan Sariah

\section{PENDAHULUAN}

\section{A. ANALISIS SITUASI}

Manusia sebagai hamba Allah SWT diperintahkan untuk memanfaatkan potensi yang berada di dalam dirinya dengan bekerja guna menghasilkan pendapatan maupun kekayaan (harta). Jenis pekerjaan yang dilakukan oleh umat manusia tidak dibatasi jenisnya, namun harus mengikuti petunjuk yang telah digariskan oleh Al-Qur'an dan Al-Hadist. Banyak sekali petunjuk yang memerintahkan manusia untuk bekerja baik sebagai pekerja mandiri (wiraswasta) maupun bekerja pada orang lain dengan mendapatkan upah. Perintah bekerja dimaksudkan agar manusia dapat memanfaatkan dan mengoptimalkan segala potensi yang ada, menghadirkan karya dan kreativitas yang bermanfaat bagi dirinya maupun orang lain.

Wiraswasta atau bekerja mandiri merupakan salah satu cara untuk menghindarkan setiap individu manusia dari sebutan sebagai seorang penganggur. Banyak jenis dan ragam pekerjaan yang dapat dikerjakan secara mandiri (berwiraswasta), bergantung pada keahlian dan potensi yang dimiliki oleh setiap individu. Bekerja secara mandiri (berwiraswasta) dapat dilakukan secara sendiri maupun secara bersama-sama yang didasari pada adanya kesamaan visi dan misi yang ingin dicapai. Dalam melakukan aktivitas usaha atau bisnis, seorang pengusaha atau wiraswastawan harus mengedepankan nilai- nilai etika bisnis. Etika bisnis adalah penerapan etika secara umum terhadap prilaku bisnis (Hamali, $\mathrm{dkk}$, 2017) 


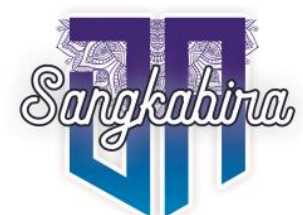

Vol. 1, No. 2, Juni 2021

Lingkungan Grisak Kelurahan Kekalik Jaya Kecamatan Sekarbela Kota Mataram merupakan salah satu sentra industri kecil/Rumah Tangga Tahu Tempe yang berada di Kota Mataram. Di lokasi ini terdapat potensi pemuda - pemudi yang melakukan aktivitas usaha baik berhubungan langsung dengan produksi Tahu Tempe maupun aktivitas - aktivitas usaha lainnya. Dalam perjalanan usahanya, berdasarkan pengamatan yang dilakukan adalah terdapat semangat yang tinggi untuk melakukan usaha secara mandiri di tengah persaingan mencari kesempatan kerja, namun di sisi lain permasalahan utama yang dihadapi adalah masih relatif minimnya pengetahuan yang berkenaan dengan pengembangan dan pengelolaan usaha terutama modal usaha.

Keterbatasan ini menyebabkan aktivitas usaha tidak bisa berkembang, dampaknya tidak dapat melanjutkan usahanya di samping aspek penjualan produk yang jangkauannya masih terbatas. Sisi lain, tidak terdapatnya lembaga keuangan non bank seperti koperasi yang dapat menjembatani kebutuhan mereka terhadap modal dalam jangka pendek. Kehadiran lembaga keuangan non bank syariah seperti koperasi syariah sangat membantu masyarakat umum termasuk pengusaha menghindari praktek pinjaman modal yang berdasarkan bunga. Menurut Abdad (2003), koperasi (syirkah) adalah suatu badan usaha di bidang perekonomian yang memiliki keanggotaan sukarela atas dasar persamaan hak, kerja sama, dan tujuannya untuk memenuhi kebutuhan para anggotanya dan masyarakat pada umumnya.

Keterbatasan untuk berhubungan dengan lembaga- lembaga keuangan yang resmi menyebabkan aktivitas usaha tidak berkembang dan tidak menutup kemungkinan mereka berhubungan dengan praktek praktek lembaga keuangan ilegal dengan memberikan bantuan modal yang diimbangi dengan bunga yang relatif tinggi. Bila hal ini terjadi, maka aktivitas usaha akan macet karena ketidakseimbangan besarnya keuntungan yang diperoleh dengan beban pengembalian pinjaman yang dirasakan berat. Tidak adanya lembaga keuangan non bank sejenis koperasi yang dapat membantu modal usaha juga menjadi faktor penyebab tidak bisa berkembangnya usaha yang dilakukan. Menurut Farid (2017), seorang pengusaha harus memperhatikan etika bisnis syariah salah satunya adalah menghindari jual beli yang bersifat ribawi. Akibat dari riba antara lain menimbulkan rasa malas bekerja, dan hilangnya rasa tolong menolong di antara sesama umat.

Berkenaan dengan permasalahan tersebut, maka pelaku aktivitas usaha sangat perlu untuk diberikan ilmu pengetahuan berkenaan dengan cara- cara memperoleh modal usaha. Ilmu pengetahuan dapat diberikan melalui bentuk penyuluhan terutama sekali tertuju pada pelaku usaha pemula. Hal ini dimaksudkan agar pelaku usaha pemula dapat mengetahui dari awal seluk beluk yang berkenaan dengan usaha termasuk cara memperoleh dan mengelola modal usaha. Dengan adanya informasi ini 
akan membantu pelaku usaha pemula untuk dapat memperoleh modal usaha sehingga mereka dapat mengembangkan usahanya dengan baik, yang bermuara pada peningkatan keuntungan yang diperoleh.

\section{B. Rumusan Masalah}

Berdasarkan uraian di atas dapat diidentifikasi berbagai permasalahan yang dihadapi oleh mitra sebagai berikut :

1. Modal Usaha yang dimiliki oleh pelaku usaha pemula masih terbatas yang berdampak relatif lambannya perkembangan usaha.

2. Keterbatasan informasi yang berkenaan dengan cara memperoleh modal usaha terutama pada lembaga - lembaga keuangan baik bank maupun non bank.

3. Pengetahuan yang berkenaan dengan sumber modal dan pengelolaan modal usaha masih raltif kurang yang berdampak pada maju dan mundurnya suatu usaha

4. Tidak adanya lembaga keuangan sejenis koperasi yang berbasis syariah yang menjamin kesinambungan modal usaha ketika dibutuhkan.

\section{Tujuan Kegiatan dan Kegunaan Kegiatan}

\section{Tujuan Kegiatan}

a. Memberikan Pengetahuan dan Pemahaman Kepada Masyarakat (Pengusaha Pemula ) tentang hal-hal yang berkaitan dengan kewiraushaan syariah.

b. Memberikan pemahaman tentang sumber-sumber modal dari lembaga keuangan bank maupun non bank yang cara pengelolaannya dilakukan secara syariah.

c. Memberikan bantuan tambahan modal kepada Pengusaha Pemula baik yang baru atau sudah menjalankan usahanya dan cara memanfaatkan modal tersebut secara syariah.

\section{Kegunaan Kegiatan}

a. Masyarakat (Pengusaha Pemula) dapat mengetahui dan memahami hal-hal yang berkenaan dengan Kewirausaan Syariah.

b. Masyarakat (Pengusaha Pemula) dapat mengetahui serta memanfaatkan sumber - sumber modal usaha yang ada terutama berasal dari lembaga-lembaga keuangan syariah baik bank maupun non bank.

c. Masyarakat (Pengusaha Pemula) dapat memanfaatkan dana pinjaman yang telah ada untuk memulai usaha atau mengembangka usaha yang sudah ada, meskipun maasih relatif kecil dan pengelolannya dilakukan secara syariah. 
Vol. 1, No. 2, Juni 2021

\section{SOLUSI DAN TARGET LUARAN}

\section{A. Solusi}

Keterbatasan pengetahuan dan informasi dari para pelaku usaha berkenaan dengan sumber dan pengelolaan modal usaha, menyebabkan mereka belum mampu mengembangkan usahanya pada jumlah yang lebih besar dan bervariatif. Berkenaan dengan hal tersebut solusi yang dilakukan adalah :

a. Memberikan pemahaman dan pengetahuan yang berkenaan dengan sumber dan pengelolaan modal usaha melalui pertemuan terbatas dengan metode ceramah dan diskusi.

b. Mendampingi dan memantau perkembangan usaha melalui pemanfaatan modal baik modal sendiri maupun modal dari pihak luat (pinjaman).

c. Memberi bantuan modal usaha sebagai dasar untuk melakukan usaha sekaligus membentuk kelompok usaha.

\section{B. Target}

Target secara umum adalah pelaku usaha pemula dapat mengembangkan usaha dengan memanfaatkan modal usaha baik yang berasal dari modal sendiri maupun yang berasal dari lembaga - lembaga keuangan baik bank maupun non bank. Dengan adanya modal usaha mereka dapat melakukan pengembangan usaha dengan melakukan diversifikasi usaha. Target Khusus adalah : (1) Mitra dapat mengembangkan modal usaha; (2) Mitra dapat melakukan diversifikasi usaha; (3) Mitra dapat membentuk lembaga keuangan sejenis koperasi syariah

\section{Luaran}

(1) Tercipta diversifikasi usaha yang dilakukan oleh pelaku usaha pemula;

(2) Tercipta lembaga keuangan non bank sejenis koperasi berbasis Syariah

\section{METODE PELAKSANAAN}

Permasalahan yang dihadapi oleh mitra dapat dipecahkan dengan melakukan kegiatan Pengabdian Kepada Masyarakat dalam bentuk kemitraan. Kegiatan yang dilakukan adalah memberikan penyuluhan dan pengetahuan tentang cara - cara memperoleh modal usaha, mengelola modal usaha serta membentuk lembaga keuangan non bank sejenis koperasi berbasis syariah atau kelompok usaha sebagai wadah internal yang dapat membantu dan memenuhi kebutuhan pelaku usaha. Pengusaha pemula perlu juga diberikan pengetahuan dan pemahaman 
tentang makna, prinsip dan etika kewirausahaan syariah sebagai pengetahuan dan pemahaman dasar dalam melaksanakan usahanya dengan cara syariah. Beberapa tahapan yang berkenaan dengan kegiatan ini adalah tahap persiapan, Pelaksaan Pembinaan dan pendampingan hingga berjalannya lembaga keuangan non bank yang dibentuk.

\section{A. Tahap Persiapan}

Tahap persiapan meliputi kegiatan yang berkenaan dengan pelaksanaan yang dilakukan oleh tim pengabdian kepada masyarakat mulai dari perencanaan, penentuan waktu pelaksanaan, jumlah peserta hingga pelaksanaan penyuluhan. Langkah awal yang dilakukan adalah menghubungi kepala lingkungan dan tokoh pemuda (ketua remaja) untuk melakukan identifikasi peserta yang relevan dengan kegiatan ini.

\section{B. Tahap Pelaksanaan}

Tahap pelaksanaan merupakan waktu diadakannya kegiatan penyuluhan yang telah ditentukan. Dalam tahap ini dilakukan tatap muka dengan peserta yang diawali dengan memberikan materi- materi dengan metode ceramah yang berkaitan dengan pemanfaatan dan pengelolaan modal usaha berbasis syariah. Selanjutnya dilakukan diskusi berekenaan dengan materi maupun permasalahan - permasalahan yang dihadapi baik pada waktu awal maupun dalam menjalankan usaha.

\section{Tahap Pembinaan dan Pendampingan}

Tahap pembinaan dan pendampingan merupakan tahap tim pengabdian melakukan pembinaan dan pendampingan terhadap lembaga keuangan non bank (koperasi berbasis syariah) yang dibentuk dengan menetapkan petugas yang bertanggung jawab terhadap jalannua le,baga tersebut. Penanggung jawab ditunjuk berdasarkan kesapakatan bersama di antara peserta. Tim juga akan mengadakan pemantauan dan pendampingan berkenaan dengan pencatatan berkenaan dengan arus keluas masuknya modal.

\section{Tahap Evaluasi Dan Pelaporan}

Tahap evaluasi dan pelaporan merupakan tahap akhitr dari kegiatan pengabdian pada masyarakat dalam bentuk kemitraan ini. Tim menyusun laporan berdasarkan berbagai permasalahan dan informasi yang diperoleh, keterkaitan sasaran dan capaian dari hasil kegiatan ini.

\section{HASIL DAN PEMBAHASAN}

\section{A. Waktu Pelaksanaan}

Kegiatan ini terlebih dahulu dilakukan kesepakatan dengan tokoh pemuda yang ditunjuk sebagai koordinator kegiatan berkenaan dengan 


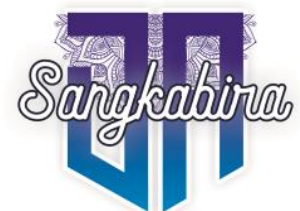

Vol. 1, No. 2, Juni 2021

waktu maupun tempat pelaksanaan, yang didahului dengan melaporkan kepada Kepala Lingkungan Grisak. Mengingat perserta pada umumnya melakukan usaha pada siang hari, maka disepakati pelaksanaan kegiatan dilakukan pada malam hari bertempat di Masjid Darul Mukhlisin Lingkungan Grisak Kelurahan Kekalik Jaya Kecamatan Sekarbela, Pelaksanaan sempat beberapa kali tertunda dari yang direncanakan awal, karena adnya kegiatan yang melibatkan calon peserta penyuluhan baik berkenaan dengan kegiatan internal lingkungan maupun kegiatan kegiatan perlombaan dalam ikut merayakan hari besar nasional seperti hari proklamasi kemerdekaan Indonesia.

Kegiatan penyuluhan baru dapat dilaksanakan pada hari Ahad, 13 Oktober 2019 bertempat di Masjid Darul Mukhlisin Ligkungan Grisak yang dimulai pada pukul 20.30 WITA hingga selesai. Kegiatan penyuluhan dihadiri oleh sebanyak 24 peserta baik berjenis kelamin laki-laki maupun perempuan. Sebahagian besar peserta bekerja sebagai pedagang, wirausaha, pelajar maupun mahasiswa. Kegiatan perdagangan yang diusahakan beraneka jenis seperti menjual pulsa, jualan di kios, barangbarang kelontong dan membantu orang tuanya menjual tahu dan tempe. Latar belakang pendidikan peserta bervariatif mulai dari SD, SMP, SMK, D3 dan S1. Dengan latar belakang pendidikan ini menjadi modal mereka melakukan usaha sesuai dengan bakat dan keahliannya masing- masing.

Kegiatan penyuluhan diawali oleh kata pengantar dari Ketua Remaja Masjid Darul Mukhlisin yang menyampaikan maksud dan tujuan dilaksanakannya kegiatan penyuluhan. Selanjutnya tim pengabdian menyampaikan materi dengan metode ceramah, disertai dengan contoh contoh kasus yang melakukan usaha bergerak dengan menggunakan modal sendiri, modal patungan maupun modal pinjaman. Materi umum yang disampaikan terdiri dari :

1. Modal Usaha dalam Ekonomi Islam meliputi makna modal secara umum dan modal usaha Islami

2. Peranan Modal Usaha Islami meliputi fungsi dan peranan modal dalam menjalani usaha secara Islami

3. Pembentukan Modal Usaha Islami meliputi langkah -langkah Islami dalam pembentukan modal usaha.

4. Sumber Modal Islami meliputi jenis - jenis dan sumber - sumber modal usaha yang berasal dari umat Islam.

Ditengah-tengah penyampaian materi penyuluhan, tim memberikan kesempatan kepada para peserta untuk memberikan pertanyaan terhadap materi yang sedang disampaikan oleh tim. Jenis pertanyaan berkenaan dengan wirausaha yang ingin dikembangkan, modal yang dimiliki, serta keterbatasan pengetahuan yang dimiliki untuk memulai usaha. Terhadap pertanyaan ini tim memberikan jawaban singkat sembari melanjutkan materi. Jawaban seutuhnya akan diberikan pada waktu diskusi dan tanya jawab. 


\section{B. Identifikasi Permasalahan Yang Dihadapi Peserta}

Materi yang disampaikan melalui metode ceramah telah menambah wawasan dan pengetahuan peserta berkenaan dengan kewirausahaan syariah. Pada waktu acara diskusi dan tanya jawab, peserta memberikan saran sekaligus harapan terhadap kegiatan ini. Beberapa pertanyaan dari peserta dan merupakan permasalahan adalah :

1. Peserta masih awam mengenai usaha-usaha yang berbasis syariah sehingga meminta diadakannya pelatihan berkenaan dengan hal tersebut.

2. Kendala utama dihadapi peserta yang akan memulai dan sudah berusaha adalah keterbatasan modal usaha baik modal lancar (uang) maupun peralatan usaha.

3. Lingkungan Grisak merupakan salah satu sentra industri rumah tangga pembuatan Tahu- Tempe di Kota Mataram. Masyarakat terutama generasi muda belum memiliki keterampilan untuk mendiversifikasi usaha. Mereka berkeinginan untuk melakukan diversifikasi usaha tidak hanya menjual Tahu-Tempe dalam bentuk asli, diolah dalam bentuk lain, agar menjadi sumber pendapatan baru selain pendapatandari Tahun - Tempe.

4. Kesulitan berhubungan dengan lembaga keuangan formal karena tidak dapat memenuhi persyaratan yang ditetapkan.

5. Butuh bantuan modal melalui lembaga sejenis koperasi atau lembaga keuangan yang tidak membebankan bunga kepada peminjam.

6. Dibutuhkan lembaga keuangan sejenis koperasi yang dapat menjembatani mereka terhadap kebutuhan modal dan kebutuhan lainnya. Dengan lembaga tersebut peserta dapat memperoleh bantuan modal baik untuk awal usaha maupun ketika usaha sudah berjalan.

7. Keterbatasan tempat untuk membuka usaha. Jika ingin menyewa biaya sangat mahal.

8. Peserta belum memahami prosedur pembentukan dan pengelolaan koperasi terutama koperasi syariah, sehingga membutuhkan penyuluhan atau pendidikan tentang Koperasi.

Berdasarkan hal ini, tim memberikan penjelasan secara umum berkenaan dengan keberadaan lembaga keuangan non bank sejenis koperasi yang menerapkan perinsip syariah. Peserta sangat tertarik dengan paparan yang disampaikan, dibutuhkan pertemuan lebih lanjut untuk membentuk sekaligus menyusun kepengurusan koperasi berbasis syariah. Permasalahan lain, menjadi perhatian tim untuk dilakukan kegiatan yang sama melalui pendidikan atau pelatihan berkenaan dengan strategi diversifikasi usaha dan memulai usaha baru.

\section{Bentuk Bantuan Modal}

Modal usaha awal bagi pengusaha pemula maupun tambahan moodal bagi pengusaha yang sudah menjalani usaha sangat diperlukan 


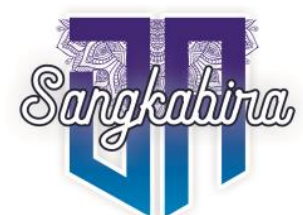

Vol. 1, No. 2, Juni 2021

untuk keberlangsungan usaha. Sebelumnya, beberapa peserta telah memanfaatkan dana pinjaman yang berasal dari pengelola dana pinjaman yang merupakan bentukan dari ketua tim penyuluhan ini. Pengelolaan keuangan ini akan menjadi cikal bakal hadirnya lembaga keuangan syariah, baik dalam bentuk lembaga pinjaman atau koperasi syariah. Dana awal yang diberikan adalah sebesar Rp 2.000.000,- dan telah digulirkan secara syariah. Tim penyuluhan telah memberikan suntikan modal untuk menambah modal usaha pada kegiatan ini sebesar Rp 1.750.000,- ( satu juta tujuh ratu lima puluh ribu rupiah),- yang dapat dimanfaatkan oleh peserta yang ingin memulai usaha atau menambah modal usaha yang sudah berjalan.

Adanya tambahan dana bantuan modal ini, diharapkan peserta dapat memanfaatkannya untuk modal awal usaha atau untuk melakukan diversifikasi usaha bagi yang telah berusaha. Hasil pengakuan peserta bahwa dengan memoanfaatkan modal ini, meras terbantu dan dapat melakukan diversfikasi usaha meskipun masih dalam jumlah yang relatif kecil, disesuaikan dengan besarnya modal pinjaman. Hal ini akan berlangsung secara bergilir, peserta akan memperoleh kesempatan yang sama menikmati dana pinjaman yang ada. Secara perlahan modal akan terus bertambah seiring dengan adanya bantuan tambahan modal dari peserta yang memanfaatkan modal pinjaman tersebut.

\section{Skema Pemberian dan Pengembalian Modal}

Penanggung jawab pengelolaan keuangan yang ditunjuk oleh ketua tim, melakukan sosialisasi kepada pengusaha pemula yang ingin memulai usaha atau kekurangan modal untuk memanfaatkan dana yang ada untuk menjadi modal awal atau menambah modal usaha yang sudah berjalan. Penganggung jawa pengelolaan keuangan melalukan diskusi dan musyawarah tentang skema pemberian pinjaman dan pengembaliannya. Hasil kesepakatan antar pemberi pinjaman dengan peminjam terlihat berikut :

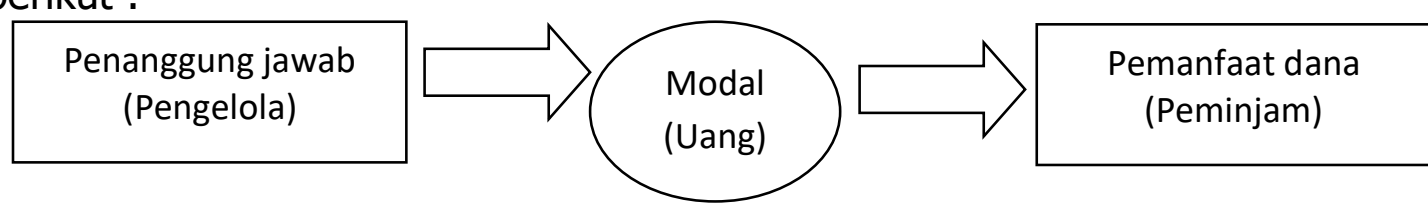

Sistem yang disepakati :

1. Pengelola menawarkan sejumlah uang untuk modal usaha atau menambah modal kepada peminjam, dengan persyaratan tertentu.

2. Persyaratan yang harus dilakukan oleh peminjam adalah membuat pernyataan kesediaan meminjam dan menulis kesediaan untuk menambah modal sesuai dengan keikhlasannya berdasarkan jangka waktu peminjamannya.

3. Penyerahan tambahan modal dilakukan pada waktu masa pinjaman berakhir yang disepakati paling lama 10 kali angsuran. 
4. Pengelolan tidak mengenakan denda bila peminjam belum mampu membayar pada salah satu priode bulan pengembalian.

5. Tidak ada paksaan kepada peserta untuk menambah modal yang sudah ada, melainkan berdasarkan keikhlasannya.

\section{E. Faktor Pendukung}

Kegiatan penyuluhan dapat berjalan dengan baik karena adanya faktor pendukung yaitu :

1. Kepala Lingkungan Gerisak yang telah memberikan dukungan penuh terhadap kegiatan ini, meskipun pada waktu kegiatan penyuluhan tidak berkesempatan hadir karena ada kegiatan yang tidak dapat ditinggalkan pada saat yang bersamaan.

2. Ketua Remaja Lingkungan Grisak yang menyambut dengan baik kegiatan ini dengan menghimpun para peserta untuk menghadiri acara ini.

3. Penanggung Jawab pengelolaan keuangan dana pinjaman yang telah mampu melaksanakan kegiatan awal yang mendorong peserta untuk lebih mengetahui tentang pengelolaan keuangan secara syariah.

4. Adanya perhatian peserta terhadap materi yang disampaikan dibuktikan dengan adanya pertanyaan dan harapan adanya kegiatan pelatihan untuk memulai usaha dari tim pada saat yang akan datang.

5. Semangat peserta untuk membentuk lembaga keuangan sejenis koperasi syariah yang menjembatani keterbatasan mereka untuk memperoleh modal untuk memulai dan melanjutkan usaha.

6. Meskipun kegiatan penyuluhan ini hanya berlansung 2 jam (20.20 22,30), peserta telah memberikan perhatian dan mendengarkan secara seksama materi yang disampaikan meskipun hanya dalam metode ceramah.

\section{F. Faktor Penghambat}

Faktor penghambat yang ditemukan antara lain :

1. Waktu pelaksanaan sempat tertunda karena adanya kesibukan dari masing - masing peserta sehingga kegiatan disesuaikan dengan waktu luang yang dimiliki peserta.

2. Kegiatan penyuluhan dilaksanakan pada malam hari setelah sholat Isya, karena peserta memiliki waktu dan dapat berkumpula hanya pada malam hari. Waktu siang hari peserta melakukan aktivitasnya masing - masing, sehingga kegiatan di malam hari tidak mengganggu aktivitas peserta.

3. Kegiatan dilakukan pada malam hari, menyebabkan kegiatan penyuluhan relatif terbatas karena keterbatasan waktu. Penyampaian materi dilakukan secara umum sehingga informasi yang berkenaan dengan materi belum dapat diterima secara utuh dan sempurna. 
4. Rencana untuk membentuk lembaga keuangan sejenis koperasi syariah belum dapat dilaksanakan, karena adanya beberapa persyaratan yang belum dapat dipenuhi seperti kesediaan peserta yang belum mau menduduki kepengurusan hanya menjadi anggota.

\section{G. Evaluasi}

Keberhasilan dari kegiatan ini dapat dilihat bari beberapa indikator sebagai berikut :

1. Kehadiran peserta yang telah melebihi syarat target dan harapan tim kegiatan penyuluhan yaitu sebanyak minimum 20 orang dan yang hadir sebanyak 36 orang.

2. Meskipun dilaksanakan pada malam hari, tidak mengurangi keingintahuan peserta baik laki - laki dan perempuan.

3. Diskusi dan tanya jawab yang memberikan gambaran tentang permasalahan yang dihadapi peserta terutama berkenaan dengan modal usaha yang berbasis syariah telah memenuhi sasaran dan target diadakannya kegiatan penyuluhan ini.

4. Peserta bersedia untuk mendukung serta menjadi anggota koperasi syariah yang akan dibentuk kelak setelah perjalan modal awal dari kegiatan ini terus mengalami perkembangan baik dari jumla modal maupun jumlah peminjam.

5. Belum dapat terwujudnya pembentukan lembaga keuangan non bank sejenis koperasi syariah seperti yang diungkapkan pada faktor penghambat di atas.

\section{H. Keberlanjutan}

Kegiatan ini akan dilanjutkan pada masa mendatang karena didukung oleh beberapa hal:

1. Peserta ingin memperoleh pengetahuan yang lebih dalam mengenai cara-cara memulai usaha dan komponen pendukungnya melalui kegiatan pelatihan atau pendidikan.

2. Peserta berkeinginan untuk membentuk lembaga keuangan non bank sejenis koperasi dengan prinsip syariah.

3. Belum terbentuknya kepenegurusan tetap pengelolaan keuangan melalui bantuan pinjaman modal yang tengah berjalan sekarang, sebagai cikal bakal koperasi berbasis syariah.

4. Diperlukan kegiatan yang sama dalam bentuk penyuluhan tentang koperasi syariah bagi warga dan remaja di lingkungan Gerisak Kekalik Jaya pada masa mendatang. 


\section{KESIMPULAN DAN SARAN}

\section{A. Simpulan}

Hasil pelaksanaan pengabdian pada masyarakat dan pembahasan di atas dapat ditarik beberapa simpulan sebagai berikut :

1. Kegiatan penyuluhan telah berjalan dengan baik, peserta memperhatikan dengan seksama materi yang diberikan disertai dengan beberapa pertanyaan yang diajukan berkenaan dengan kegiatan ini maupun kegiatan pelatihan pada masa mendatang.

2. Telah berjalan cikal bakal lembaga keuangan non bank sejenis koperasi syariah yang memberikan modal usaha bagi pengusaha pemula maupun yang sudah berusaha tanpa membebankan bunga.

3. Peserta berkeinginan hadirnya lembaga keuangan non bank sejenis koperasi yang menerapkan sistem syariah. Peserta yang telah memanfaatkan modal tersebut secara ikhlas memberikan sumbangannya untuk menambah modal.

4. Belum terbentuk lembaga keuangan non bank sejenis koperasi syariah karena adanya beberapa persyaratan yang belum dapat diwujudkan pada kegiatan ini.

5. Bagi peserta yang sudah menjalani usaha, telah melakkan diversifiksi usaha melalui dana pinjaman yang dimanfaatkannya.

B. Saran -saran

1. Tim harus menindaklanjuti keinginan peserta untuk memberikatan pelatihan kewirausahaan sekaligus membentuk lembaga keuangan non bank sejenis koperasi berbasis syariah.

2. Diperlukan alokasi dana pengabdian yang proporsional dengan kegiatan yang akan dilaksanakan pada masa mendatang.

3. Penyajian tim masih dalam bentuk ceramah, dikembangkan dalam bentuk pendidikan seperti mempraktekkan langkahlangkah memulai usaha dan modal pendukungnya.

\section{DAFTAR PUSTAKA}

Asyraf Muhammad Dawabah, 2005, The Moslem Entepreneur, Kiat Sukses Pengusaha Muslim. Zikurl Hakim, Jakarta.

Farid. 2017. Kewirausahaan Syariah. Kencana, Jakarta

Hamali, Arif Yusuf dan Eka Sari Budihastuti. 2017. Pemahaman Kewirausahaan. Kencana, Jakarta.

Husain Syahatah, Sidiq Muh Al-Amin Adh Zdhahir. 2005. Transaksi Dan Etika Bisnis Islam, Visi Insani Publishing, Jakarta. 
Saebani, Beni Akhmad dan Abdul Hamid. 2010. Ilmu Akhlak. Pustaka Setia, Bandung.

Suparyanto. 2013. Kewirausahaan Konsep Realita Pada Usaha Kecil. Alfabeta, Bandung.

Suryana. 2016. Kewirausahaan Kiat dan Proses Menuju Sukses, Salemba Empat, Jakarta.,

Suryana, Yuyus dan Kartib Ayub. 2010. Kewirausahaan Pendekatan Karakteristik Wirausahawan Sukses, Edisi Kedua. Kencana Prenada Media Group, Jakarta.

Yusanto, Muhammad Ismail dan Muhammad Karebet Widjajakusuma. 2002. Menggagas Bisnis Islami. Gema Insani, Jakarta.

Zaidi Abdad. 2003. Lembaga Perekonomian Umat Di Dunia Islam. Angkasa, Bandung.

Zulmaizarna. 2009. Akhak Mulia Bagi Pemimpin. Al-Fikriss, Bandung. 